\title{
ツマグロヨコバイにおけるカーバメート系殺虫剤抵抗性とその㙨構
}

\author{
浜弘司・岩田 俊一 \\ 農林省農業技術研究所
}

(1973 年 6 月 6 日受領)

\begin{abstract}
Resistance to Carbamate Insecticides and Its Mechanism in the Green Rice Leafhopper, Nephotettix cincticeps Uhler. Hiroshi Hama and Toshikazu Iwata (Division of Entomology, National Institute of Agricultural Sciences, Nishigahara, Kita-ku, Tokyo 114) Jap. J. appl. Ent. Zool. 17 : 154-161 (1973)

Seven populations of the green rice leafhopper, Nephotettix cincticeps, used in this study were collected in the fields where carbamate insecticides had become ineffective. They showed high resistance to carbamate insecticides at the same or a little less degree as the Nakagawara strain, and their resistance spectrum against carbamate insecticides were also similar to that obtained in the Nakagawara strain. Synergistic effects of piperonyl butoxide, tri-o-crecyl phosphate and triphenyl phosphate to carbamate insecticides were not remarkable in four of the resistant populations tested as in the case of a susceptible strain. Cholinesterase obtained from the seven resistant populations showed almost the same level of activity, but the enzyme from the resistant populations was much less inhibited by the carbamate insecticides than that from the susceptible strain. In the moderately resistant Ôzu population, a plateau wa: observed at about $70 \%$ mortality on the dosage-mortality curve. In this population a decline of sensitivity of the cholinesterase to carbamate insecticides was also detected. These result: suggested that the resistance in the resistant populations used in this study was caused by lowered sensitivity of cholinesterase to the insecticides as previously shown in the Nakagawara strain. Therefore, the presence of the less sensitive cholinesterase is considered to be a general mechanism of carbamate-resistance in this insect.
\end{abstract}

ツマグロヨコバイのカーバメート系殺虫剤抵抗性は 1969 年に爱媛県松山市松前町で最初に発見されて以来, 翌 1970 年には広島県下で，また 1972 年には九州の数 力所で次々に報告され，さらになおその分布は拡大しそ うな状況にある（岩田・浜, 1973 参照)。

著者らは，最初に本種のカーバメ一ト剂抵抗性が問題 となった愛媛県松前町中川原で採集したツマグロヨコバ イ（以下中川原系統という）を用いカーバメート棛抵抗 性の機構を検討し，この抵抗性が従来イエバエなど他種 の昆虫で知られているような解毒分解活性の増大による のではなく，この薬剤の作用点と考えられているアセチ ルコリンエステラーゼ (ChE) の本剤に対する感受性低 下によることをほぼ明らかにした（岩田・浜，1971； Hama and Iwata, 1971)。

$\mathrm{ChE}$ の薬剤に対する感受性低下の現象は，ナ之ハダ = (Smissaert, 1964 ; Voss and Matsumura, 1964)
やオウシマダニ (LEE and BATHAM, 1966 ; WhARTON and Roulston, 1970) などダ二類の薬剤抵抗性機構と して知られているが，昆虫では従来この種の現象は知ら れていなかった。そこでこの現象がッマグロヨコバイの カーバメート剂抵抗性㙨構として一般的なものであるか 否かを確かめるため，他地域に発生したカーバメート剂 抵抗性個体群について, 抵抗性発達の程度とカーバメ一 卜剂に対する共力剤の効果および ChE 活性とそのカー バメート郕に対する感受性を測定し，一部すでに報告し た感受性系統ならびに中川原系統の結果と比較, 検討し た。

本文に入るに先だち，供試虫の採集にご便宜をいただ いた愛媛県農業試験場吉岡幸治郎氏，広島県農業試験場 藤原昭雄氏，鹿児島県農業試験場原敬一 . 堀切正俊 . 馬場口勝男氏らならびに供試虫をご分譲いただいた保土 谷化学工業株式会社黑須泰久氏各位に厚くお礼申し上げ

1 本報の一部は 昭和 47 年度日本応用動物昆虫学会大会（静岡）で講演した。 
第 1 表 供試したツマグロヨコバイの採集地と採集時期

\begin{tabular}{|c|c|c|}
\hline 個体群名 & 採集 & 採集時期 \\
\hline 感受性（Ｓ） & 宮城県仙台市 & 1969 年 秋 \\
\hline 中川原（ $\mathrm{N}$ ) & 愛媛県松山市松前町中川原 & 1970 年 夏 \\
\hline 大 洲 & " 大洲市 & 1971 年 春 \\
\hline 吉 田 & 広島県高田郡吉田町 & 1971 年 夏 \\
\hline 新 和 & 熊本県天草郡新和町 & 1972 年 秋 \\
\hline 鹿 屋（かのや） & 鹿児島県鹿屋市 & 1972 年 晚秋 \\
\hline 知 覧(ちらん) & " 川辺郡知覧町 & " \\
\hline 加世田 & 加世田市 & " \\
\hline 頴 娃 (え い) & 揖宿郡頴娃町 & " \\
\hline 吾 平 (あいら) & 肝属郡吾平町 & " \\
\hline
\end{tabular}

る。

\section{材料 と方法}

供試虫：実験に用いたツマグロヨコバイの採集地，採 集時期は第 1 表のとおり。採集した各個体群は室内でイ ネの芽出しを与え 1〜2 世代飼育後実験に供試したが， 熊本の新和個体群は採集後室内で 4〜5 世代経過した虫 を譲り受け，さらに 2〜3 世代飼育した後に供試した。 実験にはすべて羽化後 4〜8 日の成虫を用いた。

供試薬剤：以下に示す 11 種類のカーバメート系殺虫 剂と 3 種の共力剤を用いた。殺虫剤は下記の純度の原体 あるいはそれを精製して供試した。共力剤はいずれも東 京化成工業製の試薬である。

CPMC（ホップサイド）純度 93\%，o-chlorophenyl methylcarbamate ; MTMG（ツマサイド) 98.0\%， mtolyl methylcarbamate ; MPMC (メオバール) 98.0\%, 3,4-xylyl methylcarbamate; XMG（マクバール） 96.2 $\%$, 3,5-xylyl methylcarbamate; カーバノレート精製 品, 2-chloro-4, 5-xylyl methylcarbamate ; APG (ハイ ドロール）精製品, 4-diallylamino-3,5-xylyl methylcarbamate ; MIPG(ミプシン) 精製品, a-cumenyl methylcarbamate ; BPMC (バッサ) 97\%, o-sec-butylphenyl methylcarbamate ; PHC（サンサイド）精製品， o-isopropoxyphenyl methylcarbamate; NAC 98\%, 1naphthyl methylcarbamate; メソミル 90\%, S-methyl $\mathrm{N}$-(methylcarbamoyloxy) thioacetimidate。

共力剂, piperonyl butoxide(p. b. と略), tri-o-cresyl phosphate (TOGP), triphenyl phosphate (TPP)。

殺虫試験法 : 殺虫試験は前報（岩田・浜，1971）に準 じて行なった。すなわち殺虫刜を所定の濃度にアセトン で希勫し，雌成虫背面に 1 頭当り $0.5 \mu l$ を局所施用し た。処理した虫はイネの芽出しを入れたポリ容器に収容 し, $27 \pm 1.5^{\circ} \mathrm{C}$ の定温室に置き, 24 時間後に生死を判 定した。共力作用試験では共力剤とカーバメート棛を混
合したアセトン溶液を処理する方法と共力剤を先に処理 し，60 分後にカーバメート㘊を処理する方法を試みた。 処理方法は上の 殺虫試験法に準じて行ない， SUN and JoHNSON (1960) に従って共力作用係数 (co-toxicity coefficient）を計算した。

ChE 活性の測定法 : ChE 活性は前報 (HAMA and IwATA，1971）に準じて測定した。すなわち成虫を 1/15M リン酸緩衝液, $\mathrm{pH} 7.2(8 \sim 10$ 頭成虫 $/ \mathrm{m} l)$ でガラスホ モゲナザーを用い摩砕し，ナイロン布でろ過した液を酵 素液とした。この酵素液 $1 \mathrm{ml}$ と $0.004 \mathrm{M}$ アセチルコ リン・ブロマイド（リン酸緩衝液で希棌したもの） $1 \mathrm{ml}$ を試験管に入れ, $37^{\circ} \mathrm{C}$ の恒温槽で 30 分（一部 40 分） 反応させた後，残存している基質を Hestrin 法で発色さ せて比色定量した。

$\mathrm{ChE}$ 活性のカーバメート剂による阻害実験では, 阻害 剂が酵素液中で所定の濃度になるように阻害剤のアセト ン溶液をマイクロシリンジで一定量とり，溶媒を蒸発さ

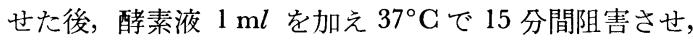
次いで $1 \mathrm{~m} l$ のアセチルコリン液を加えさらに 30 分反応 させ阻害されていない ChE 活性を測定した。

結果

\section{1. 各個体群のカーバメート撤に対する抵抗性発達の 程度}

吉田個体群に対する各種カーバメート剂の $\mathrm{LD}_{50}$ を第 2 表に, 九州各地の抵抗性個体群に対する 3 種カーバメ 一ト剂の $\mathrm{LD}_{50}$ を第 3 表に，またそれらの薬量一死虫率 の関係を大洲，その他 $2 ， 3$ の個体群と比較して第 1 , 2,3 図に示した。吉田個体群に対する各種カーバメ一 ト剂の $\mathrm{LD}_{50}$ は，PHC と NAC が少し低いほかは，中 川原系統の值と近似していた。また，九州各地の抵抗性 個体群の $\mathrm{LD}_{50}$ も中川原系統と同じ傾向を示し，いずれ の個体群も PHG には非常に高く, 次いで MTMC, NAC の順であった。しかし，個体群の間でやや細かく 
第 2 表 吉田個体群䧳成虫に対する各種カーバメート棛の $\mathrm{LD}_{50}$ と抵抗性比

\begin{tabular}{|c|c|c|c|c|}
\hline & \multicolumn{3}{|c|}{$\mathrm{LD}_{50}(\mu \mathrm{g} / \mathrm{g}$ 虫体重 $)$} & \multirow{2}{*}{$\begin{array}{c}\text { 吉田の抵抗性比 } \\
\text { (吉田のLD } \\
50 / \mathrm{S} \text { L } \mathrm{LD}_{50} \text { ) }\end{array}$} \\
\hline & 感受性（S） & 中川原 (N) & 吉 田 & \\
\hline MIPC（ミプシン） & 2.3 & 220 & 180 & 78 \\
\hline BPMC（バッサ） & 1.6 & 200 & 170 & 106 \\
\hline PHC（サンサイド） & 2.6 & 440 & 180 & 69 \\
\hline CPMC（ホップサイド） & 3.8 & 52 & 47 & 12 \\
\hline MTMC（ツマサイド） & 4.3 & 81 & 61 & 14 \\
\hline MPMC（メオバール） & 2.6 & 62 & 55 & 21 \\
\hline XMC（マクバール） & 2.6 & 74 & 78 & 30 \\
\hline カーパノレート & 0.62 & 43 & 33 & 53 \\
\hline APC（ハイドロール） & 0.62 & 23 & 16 & 26 \\
\hline NAC & 0.71 & 71 & 22 & 31 \\
\hline メソミル & 0.29 & 3.8 & 2.7 & 9.3 \\
\hline
\end{tabular}

第 3 表 各個体群雌成虫に対する 3 種カーバメート剤の $\mathrm{LD}_{50}$

\begin{tabular}{|c|c|c|c|c|c|c|c|c|c|}
\hline & \multicolumn{9}{|c|}{$\mathrm{LD}_{50}(\mu \mathrm{g} / \mathrm{g}$ 虫体重) } \\
\hline & 感受性 (S) & 中川原 $(\mathrm{N})$ & 吉 田 & 新 和 & 鹿 屋 & 知 覧 & 加世田 & 頴 娃 & 吾 平 \\
\hline PHC（サンサイド） & 2.6 & 440 & 180 & 250 & $138^{*}$ & $225 *$ & 313 & $120^{*}$ & $250^{*}$ \\
\hline MTMC（ツマサイド） & 4.3 & 81 & 61 & 63 & 70 & 68 & 118 & 38 & 50 \\
\hline NAC & 0.71 & 71 & 22 & 35 & 33 & 40 & 38 & 19 & 33 \\
\hline
\end{tabular}

注 * 薬量一死虫率曲線で直線がみだれたもので，おおよその值を示した。

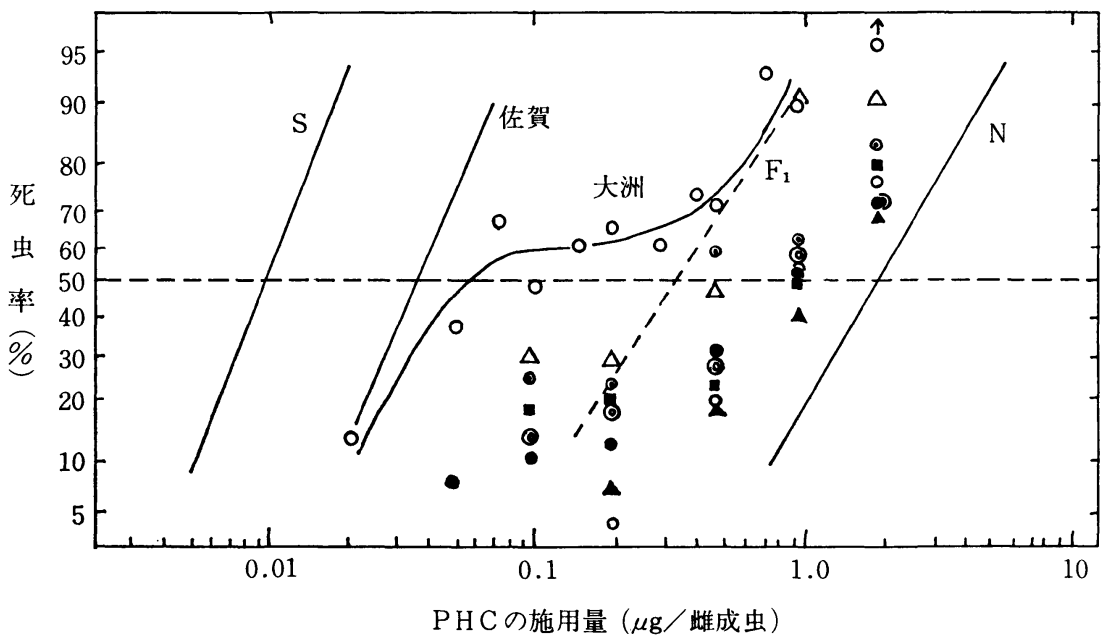

第1図 各個体群における PHC の薬量一死虫率の関係。

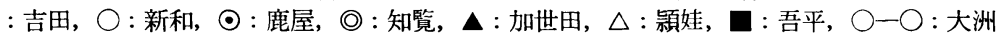
各個体群， $\mathrm{F}_{1}(---)$ は $\mathrm{S} \times \mathrm{N}$ の $\mathrm{F}_{1}$ 世代を，佐賀（一）は佐賀個体群を示し，参考にのせた。 $\uparrow:$ 死虫率 $100 \%, \downarrow:$ 死虫率 $0 \%$ （なお, 薬量 $5 \mu \mathrm{g} /$ 雃成虫の死虫率は, いずれの個体群も $100 \%$ であった)。

比較すると, 中川原系統は PHC と NAC に, 加世田 個体群は PHC と MTMG に他の個体群に比べて高い 值を示し, 頴娃個体群はいずれの薬剤に対しても供試し た抵抗性個体群の中では最も低い值であった。

3 種カーバメート剤の薬量一死虫率の関係をみると,
吉田, 新和, 加世田個体群では 3 種カーバメート棛に対 しほぼ直線にのり, 中川原系統と同等か多少低い程度で あったが，鹿児島県のほかの個体群では特に PHC に対

して死虫率の低いところで直線がみだれた。

また大洲個体群における 3 種カーバメート用の薬量一 


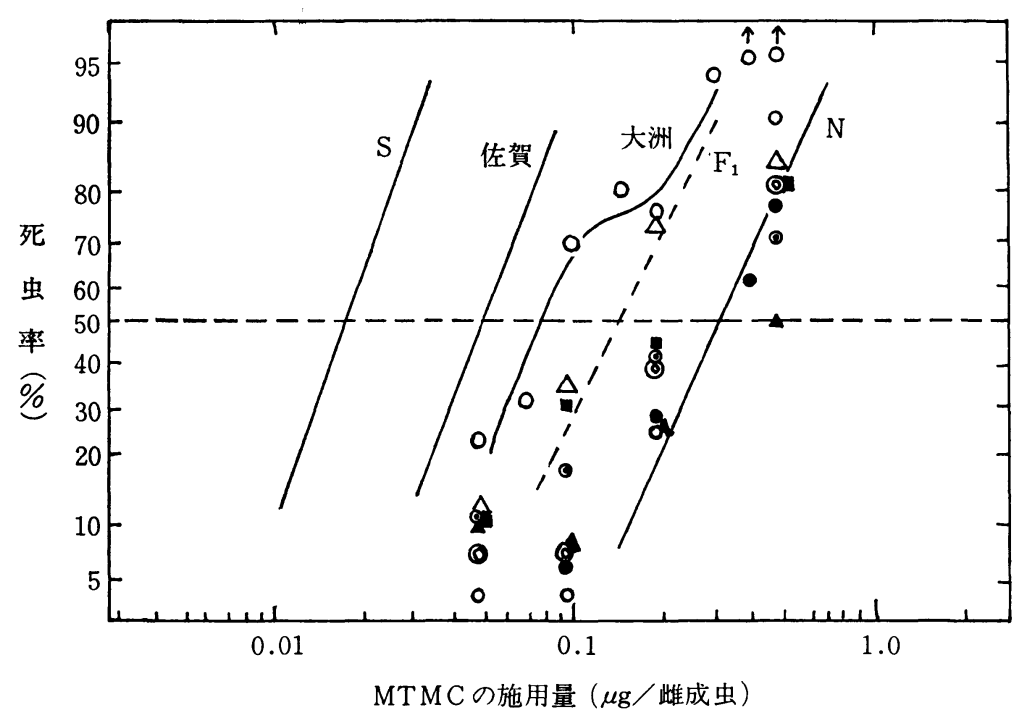

第 2 図各個体群における MTMC の薬量一死虫率の関係。説明は第 1 困に同じ。

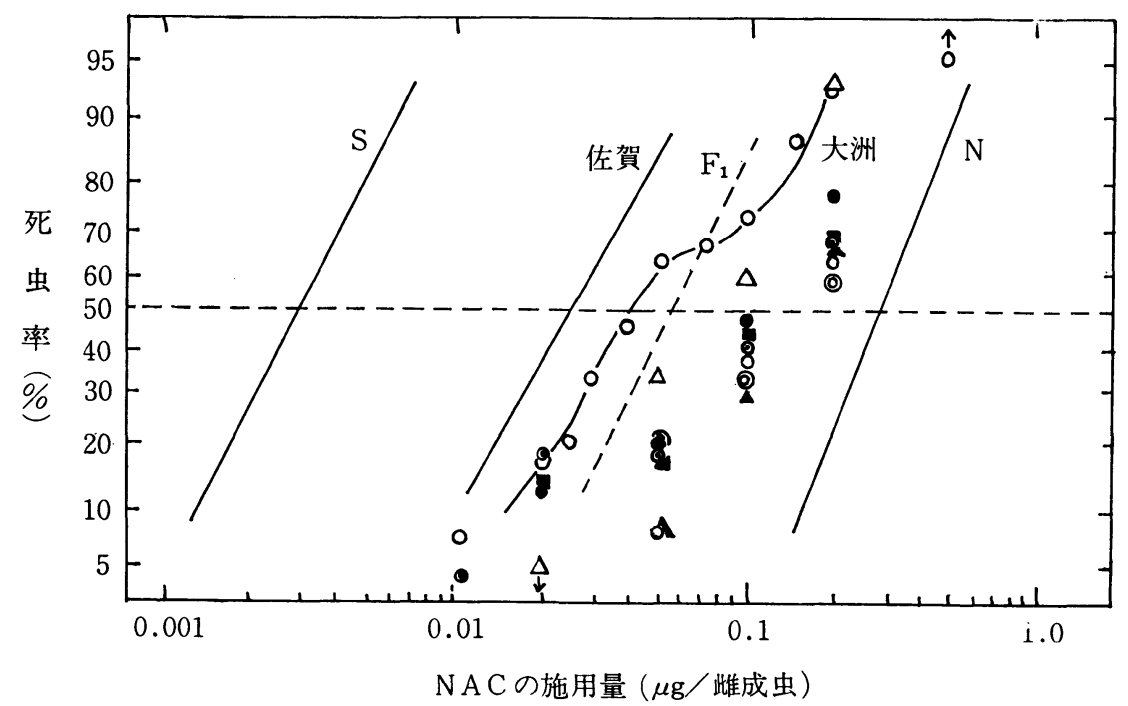

第3図各個体群における NAC の薬量一死虫率の関係。説明は第 1 困に同じ。 （なお, 薬量 $0.5 \mu \mathrm{g} /$ 䃾成虫の死虫率は, いずれの個体群も $100 \%$ であった）

死虫率曲線はいずれも死虫率 $70 \%$ 付近に明瞭なプラト ウが認められた。

\section{2. 各個体群のカーバメート刻に対する 3 種共力剤の} 作用

抵抗性の吉田, 新和, 鹿屋, 知覧の各個体群, 中川原 系統および感受性系統を用いて，PHC に対する p. b., TOCP, TPP の共力作用を検討した結果は第 4 表に示 すとおり, 吉田, 新和, 知覧個体群で p. b. の共力効果
が多少認められるが，TOCP，TPP の効果はいずれの 個体群においても認められなかった。なお，第 4 表に示 した感受性, 中川原両系統および吉田個体群に 対する PHC の $\mathrm{LD}_{50}$ が，第 3 表に示した值と多少異なってい るが，これは共力作用の試験と同時に行なった值を採用 したためで，その違いは累代飼育中の薬剤感受性の変動 や試験誤差によるものと考えられる。 
第 4 表 各個体群雌成虫に対する PHC と p.b., TOCP, TPP の共力作用

\begin{tabular}{|c|c|c|c|c|c|c|c|}
\hline & \multicolumn{7}{|c|}{$\mathrm{LD}_{50}(\mu \mathrm{g} / \mathrm{g}$ 虫体重） } \\
\hline & 感受性(S) & 中川原 $(\mathrm{N})$ & 吉 & 新 & 和 & 屋 & 覧 \\
\hline PHC（サンサイド） & 2.0 & 263 & 263 & \multicolumn{2}{|c|}{250} & 138 & 225 \\
\hline $\mathrm{PHC}+$ p.b. & $2.0(100)$ & $238(111)$ & $188(140)$ & \multicolumn{2}{|c|}{$188(133)$} & $125(110)$ & $125(180)$ \\
\hline $\mathrm{PHC}+\mathrm{TOCP}$ & $1.88(106)$ & $313(84)$ & $225(117)$ & \multicolumn{2}{|c|}{-} & - & - \\
\hline $\mathrm{PHC}+\mathrm{TPP}$ & - & - & - & \multicolumn{2}{|c|}{$238(105)$} & $163(85)$ & $275(82)$ \\
\hline \multirow{2}{*}{\multicolumn{8}{|c|}{ 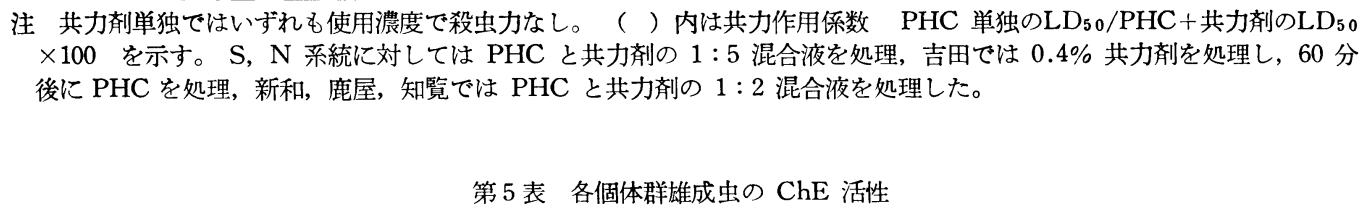 }} \\
\hline & & & & & & & \\
\hline & \multirow{2}{*}{\multicolumn{2}{|c|}{$\frac{\text { 虫 体 重 }}{(\mathrm{mg} / \text { 成虫 }}$}} & \multicolumn{5}{|c|}{ アセチルコリン分解量 } \\
\hline & & & \multicolumn{3}{|c|}{$\mu \mathrm{M} /$ 成虫 $/ 30$ 分 } & \multicolumn{2}{|c|}{$\mu \mathrm{M} / \mathrm{g}$ 虫体重/30分 } \\
\hline 感受性 （S） & \multicolumn{2}{|c|}{$\begin{array}{c}2.71 \pm 0.06 \\
(4.35 \pm .08)\end{array}$} & \multicolumn{3}{|c|}{$\begin{array}{c}0.197 \pm 0.009 \\
(.312 \pm .007)\end{array}$} & \multicolumn{2}{|c|}{$\begin{array}{c}72.8 \pm 4.9 \\
(71.7 \pm 1.4)\end{array}$} \\
\hline 中川原 $(\mathrm{N})$ & \multicolumn{2}{|c|}{$\begin{array}{c}2.40 \pm .08 \\
(3.97 \pm .12)\end{array}$} & \multicolumn{3}{|c|}{$\begin{array}{l}.289 \pm .009 \\
(.300 \pm .004)\end{array}$} & \multicolumn{2}{|c|}{$\begin{array}{l}121.1 \pm 6.8 \\
(75.5 \pm 0.9)\end{array}$} \\
\hline 吉 田 & \multicolumn{2}{|c|}{$(4.63 \pm .06)$} & \multicolumn{3}{|c|}{$(.388 \pm .013)$} & \multicolumn{2}{|c|}{$(84.0 \pm 2.7)$} \\
\hline 新 和 & \multicolumn{2}{|c|}{$2.60 \pm .08$} & \multicolumn{3}{|c|}{$.245 \pm .008$} & \multicolumn{2}{|c|}{$94.9 \pm 5.9$} \\
\hline 鹿 屋 & \multicolumn{2}{|c|}{$2.56 \pm .04$} & \multicolumn{3}{|c|}{$.239 \pm .009$} & & $=3.4$ \\
\hline 知 覧 & $2.57=$ & .08 & .246 & .003 & & & $=1.4$ \\
\hline 加世田 & $2.62=$ & .03 & .247 & .015 & & & $=6.6$ \\
\hline 頴 娃 & $2.61=$ & .02 & .234 & .007 & & & $=3.2$ \\
\hline 吾 平 & $2.52=$ & .08 & .225 & .012 & & & $=7.6$ \\
\hline
\end{tabular}

注 4 〜 回反復の平均值 \pm S. E. （ ）内は雌成虫を用い，反応時間 40 分の分解量を示す。

第 6 表 吉田, 大洲個体群此成虫における $\mathrm{ChE}$ 活性のカーバメート棛に対する感受性

\begin{tabular}{|c|c|c|c|c|}
\hline & \multicolumn{4}{|c|}{$50 \%$ 阻害濃度, $\mathrm{I}_{50}(\mathrm{M})$} \\
\hline & 感受性 (S) & 中川原 $(\mathrm{N})$ & 田 & 大 \\
\hline PHC（サンサイド） & $1.3 \times 10^{-5}$ & $1.5 \times 10^{-3}(120)$ & $7.0 \times 10^{-4}(54)$ & $1.0 \times 10^{-4}(8)$ \\
\hline MTMC (ツマサイド) & $2.4 \times 10^{-5}$ & $4.0 \times 10^{-4}$ & $4.0 \times 10^{-4}(17)$ & $5.0 \times 10^{-5}(2)$ \\
\hline NAC & $1.4 \times 10^{-6}$ & $6.0 \times 10^{-5}$ & $4.2 \times 10^{-5}(30)$ & $1.3 \times 10^{-5}(9)$ \\
\hline
\end{tabular}

注（）内は 各抵抗性個体群の $\mathrm{I}_{50} / \mathrm{S}$ の $\mathrm{I}_{50}$ を示す。

第 7 表 各個体群雄成虫における ChE 活性のカーバメート剤に対する感受性

\begin{tabular}{lccccccccccc}
\hline & \multicolumn{8}{c}{$\mathrm{ChE}$ 活性のカーバメートによる阻害度 (\%) } \\
\cline { 2 - 9 } & 感受性 $(\mathrm{S})$ & 中川原 $(\mathrm{N})$ & 新 & 和 & 鹿 & 屋 & 知 覧 & 加世田 & 頴 & 娃 & 吾 平 \\
\hline PHC (サンサイド) & 87.1 & 23.9 & 18.5 & 20.3 & 13.6 & 14.6 & 35.4 & 19.8 \\
MTMC (ツマサイド) & 76.2 & 28.0 & 22.2 & 28.3 & 18.8 & 25.3 & 38.9 & 31.6 \\
NAC & 80.2 & 31.8 & 25.5 & 30.7 & 24.1 & 24.4 & 39.7 & 27.9 \\
\hline
\end{tabular}

注 阻害度=阻害刘により 阻害された $\mathrm{ChE}$ 活性/阻害削を含まない場合の $\mathrm{ChE}$ 活性 $\times 100$, 反復 2 回の平均值（2 回の值 はいずれも類似した)。阻害剂の酵素液中の濃度 : PHC ; $10^{-4} \mathrm{M}, \mathrm{MTMC} ; 10^{-4} \mathrm{M}, \mathrm{NAC} ; 10^{-5} \mathrm{M}$, 阻害時間 : 15分。 


\section{3. 各個体群の $\mathrm{j} C \mathrm{ChE}$ 活性とそのカーバメート甋に対 する感受性}

各個体群の. ChE 活性は第 5 表の通りで，各抵抗性個 体群の ChE 活性は吉田個体群が中川原系統に比べ多少 高いほかはほほぼ同等の活性であった。

次に各個体群の $\mathrm{ChE}$ 活性のカーバメート䨩に対する 感受性は第 6 表抢よび第 7 表の通りで, 抵抗性個体群は いずれも感受性系統に比べて感受性が著しく低下してい た。3 種カーバメート霍に対する感受性は第 7 表に示す ようにいずれも中川原系統と同様, PHC に対し最も低 く, 次いで MTMG，NAC の順であった。また頴娃個 体群では他の個体群に比べて多少感受性低下の程度が小 さかった。

また，第 6 表に示すように大洲個体群でも $\mathrm{ChE}$ の感 受性低下が認められ，その程度は感受性系統と中川原系 統のほぼ中間であった。

$$
\text { 考察 }
$$

著者らは，中川原系統のツマグロヨコバイに打けるカ ーバメート戍抵抗性の機構についてすでにほぼ明らかに した。すなわち, カーバメートの解毒分解過程の阻害剂 として知られる p. b. の PHC や NAG に対する共力 作用が，中川原系統でも感受性系統と同様滥著でなく (岩田・浜, 1971), ChE 活性には両系統で著しい差は認 められないが，そのカーバメート棛に対する感受性が中 川原系統では感受性系統に比べ著しく低下しており, 各 種カーバメート棛の抵抗性比（中川原系統の $\mathrm{LD}_{50}$ 感受 性系統の $\mathrm{LD}_{50}$ ） と $\mathrm{ChE}$ 活性のカーバメート剂に対する 感受性の比（中川原系統の $\mathrm{ChE}$ に対する $\mathrm{I}_{50}$ /感受性系 統の $\mathrm{ChE}$ に対する $\left.I_{50}\right)$ との間に高い相間関係が認めら れた (HAMA and IWATA, 1971)。一方, 交配実験から このカーバメート剤抵抗性は遺伝的に不完全優性の単一 因子に支配されていて（浜·岩田，1971），この抵抗性と $\mathrm{ChE}$ 活性のカーバメート棛に対する感受性低下とは遺 伝学的に分離しえないことが確認されている（浜, 未発 表)。著者らは,これらの結果から中川原系統のカーバメ 一ト剤抵抗性はカーバメート剂に対して感受性の低下し た ChE が扔もな原因であろうと考察している。

供試した広島, 熊本, 鹿児島県下の抵抗性個体群の各 種カーバメート棛に対する抵抗性発達の程度は, いずれ も中川原系統と同等かやや低く（第 1 3 図）。各個体群 のカーバメート唷に対する抵抗性スペクトルも中川原系 統と同様のようで, 第 3 表で供試した 3 種のカーバメ一 ト棛の中では置換フェニルに長いアルコキシルの側鎖を
もつPHC に対して特に高い抵抗性を示している。

これらの個体群のうち吉田, 新和, 加世田個体群は薬 量一死虫率曲線が直線にのり, ほぼ均一な抵抗性個体群 といえるが, 鹿児島県下の鹿屋, 知覧, 頻娃, 吾平個体 群では $20 \%$ 前後の比較的感受性の高い個体の混在が示 唆された。

カーバメート抵抗性イエバエではカーバメートの解毒 分解活性が著しく高まっており, 酸化酵素活性の阻害剂 である p. b. などの化合物をカーバメートと処理するこ とにより抵抗性が著しく低下するという（MOOREFIELD， 1960 ; GeORghiou and Metcalf，1961)。ただし，こ の種の阻害剂により抵抗性レベルがそれ程低下しない系 統も知られている (GeORGHIOU，1962)。また，イエバ エではエステラーゼの阻害威である TOCP がカーバメ 一トの共力戍となることが報告されている（METCALF and Fukuto, 1965)。

そこで, ツマグロヨコバイの抵抗性個体群に対する p. b. と, エステラーゼの阻害郕である TOGP, TPP の 共力作用を検討したが，いずれの個体群でも 3 種化合物 の顕著な効果は認められなかった。よってこれらの化合 物に影響されるような解毒分解の経路はツマグロヨコバ イにおけるカーバメート用抵抗性のおもな要因とはなっ ていないといえる。

一方, 抵抗性個体群の $\mathrm{ChE}$ 活性は中川原系統より多 少低いようであるが，吉田個体群を除きほとんど同等の 活性であった。これら個体群の ChE 活性のカーバメー 卜凨に対する感受性は感受性系統に比べて著しく低下し ていた。第 7 表に示すように 3 種カーバメート唷に対す る $\mathrm{ChE}$ 活性の感受性はいずれの個体群も PHC に対し 最も低く, 次いで MTMC, NAC の順であり, $\mathrm{LD}_{50}$ の 值が高いもの程 $\mathrm{ChE}$ 活性の感受性は低い傾向が認めら れた。また抵抗性発達が比較的低かった頴娃個体群では ChE 活性の感受性低下も小さかった。よって, これら の個体群のカーバメート郕抵抗性は中川原系統と同様な 機構によるものと推察される。

大洲個体群ではカーバメート䨩の薬量一死虫率曲線で 死虫率 70\% 付近にプラトウが認められ，この個体群は 約 30\%の抵抗性因子をもった個体と約 70\% の比較的 感受性の高い個体を含む不均質な集団といえる。この 個体群の $\mathrm{ChE}$ 活性は感受性系統とほとんど違わない (Hama and IwaTA，1971) が，そのカーバメート棛に 対する感受性は明らかに低下しており，その程度は中川 原系統と感受性系統のほぼ中間であった。

大洲個体群に混在する約 70\% の感受性の高い個体の 
薬量一死虫率曲線は感受性系統（S）の直線と比較する とかなり右側によっていることがわかる(第1〜3図)。 このような野外採集個体群間の比較には過去の薬片選択 を含めた地域差を考虑しなければならないため単純な考 察は危険であるが，大洲個体群に含をれる比較的感受性 の高い個体群の部分は先に報告した佐賀, 藤枝両個体群 の直線（岩田・浜, 1971，第 1 3 図に佐賀個体群を示 した）によく近似する。佐賀，藤枝両個体群ではカーバ メート棛の薬量一死虫率曲線は直線にのりほぼ均一な集 団と考学られている。また佐賀個体群ではカーバメート 剂に対する共力剤の効果がほとえどなく， $\mathrm{ChE}$ 活性の カーバメート郕に対する感受性低下も認められていない (未発表)。したがって，大洲個体群ではカーバメート骩 に対しやや感受性が低下した個体群から中川原系統のよ うな機構による抵抗性を生じたように思われる。

なお，前田・守谷 (1973) は熊本県新和町と鹿児島県 吾平町で 1972 年春に採集した個体群に対するカーバメ 一ト棛の薬量一死虫率曲線で, 死虫率 50\% 付近に大洲 個体群と同様なプラトウを認めている。このように野外 の個体群で薬量一死虫率曲線にプラトウが観察されるこ とは, ツマグロヨコバイのカーバメート戍抵抗性の遺伝 支配が単純なものであろうという著者らの考察を裏づけ るものといえる。

以上の結果, 供試した個体群のカーバメート剂抵抗性 は中川原系統と同様, ChEのカーバメート剤に対する感 受性の低下がおもな原因であると考元られ，この現象は ツマグロヨコバイのカーバメート率抵抗性ではかなり一 般的であるといえよう。

摘要

ツマグロヨコバイの中川原系統におけるカーバメート 凰抵抗性は薬郕に対する $\mathrm{ChE}$ の感受性低下がおもな原 因であると考元られているが，この現象が本種のカーバ メート棛抵抗性の機構として一般的なものであるか否か を他地域で発生しているカーバメート剂抵抗性個体群に ついて検討した。

広島, 熊本, 鹿児島県の七つの抵抗性個体群はカーバ メ一ト剂に対し中川原系統と同等かやや低い抵抗性発達 を示し，またそれらの個体群の抵抗性スペクトルは中川 原系統と同様の傾向を示した。

P. b., TOCP, TPP の 3 種化合物のカーバメート棛に 対する共力作用はいずれの個体群でも顕著でなかった。

抵抗性個体群の ChE 活性法吉田個体群がやや高いほ かはほぼ同等であったが，そのカーバメート棛に対する
感受性はいずれの個体群も感受性系統に比べると著しく 低かった。GhE 活性の感受性低下は高い抵抗性を示し たPHC に対して著しかった。

大洲個体群ではカーバメート棛の薬量一死虫率曲線で 死虫率 70\% 付近にプラトウが認められ，さらに $\mathrm{ChE}$ のカーバメート剮に対する感受性も低下していた。

以上の結果から，供試した個体群のカーバメート唷抵 抗性は中川原系統と同様な ChE の薬剤に対する感受性 低下が打もな原因であると考光られる。

\section{引用文 献}

Georghiou, G. P. (1962) Carbamate insecticides : Toxic action of synergized carbamates against twelve resistant strains of the house fly. J. Econ. Ent. 55: 768 $\sim 772$.

Georghiou, G. P. and R. L. Metcalf (1961) The absorption and metabolism of 3-isopropylphenyl Nmethyl carbamate by susceptible and carbamate-selected strains of house flies. J. Econ. Ent. $54: 231 \sim 233$.

浜 弘司・岩田俊一 (1971) ッマグロヨコバイにおけるカーバメ 一上系殺虫剂抵抗性. 昭和 46 年度応動昆大会講演.

Hama, H. and T. Iwata (1971) Insensitive cholinesterase in the Nakagawara strain of the green rice leafhopper, Nephotettix cincticeps UHLER (Hemiptera: cicadellidae), as a cause of resistance to carbamate insecticides. Appl. Ent. Zool. $6: 183 \sim 191$.

岩田俊一・浜 弘司 (1971) カーバメート系殺虫剂抵抗性のッマ グロヨコバイについて. 防虫科学 $36: 174 \sim 179$.

岩田俊一・浜 弘司 (1973) カーバメート采殺虫郕に対するッマ グロヨコバイの抵抗性. 植物防疫 $27: 165 〜 169$.

LeE, R. M. and P. Batham (1966) The activity and organophosphate inhibition of cholinesterases from susceptible and resistant ticks (Acari). Ent. exp. appl. $9: 13 \sim 24$.

前田洋一 ·守谷茂雄 (1973) ッマグロヨコバイのカーバメート采 殺虫䯇抵抗性について（1）各種薬绪に対する感受性. 昭和 48 年度応動昆大会講演.

MetcalF, R. L. and T. R. Fukuto (1965) Effects of chemical structure on intoxication and detoxication of phenyl N-methylcarbamates in insects. J. agr. Food Chem. $13: 220 \sim 231$.

MooRefield, H. H. (1960) Insect resistance to the carbamate insecticides. Mis. Publ. Ent. Soc. Amer. $2: 145 \sim 152$.

Smissaert, H. R. (1964) Cholinesterase inhibition in spider mites susceptible and resistant to organophosphate. Science 143: 129 131. 
Sun, Y. P. and E. R. Johnson (1960) Analysis of joint action of insecticides against house flies. J. Econ. Ent. 53 : 887 892.

Voss, G. and F. Matsumura (1964) Resistance to organophosphorus compounds in the two-spotted spider mite : two different mechanisms of resistance. Nature $202: 319 \sim 320$.

Wharton, R. H. and W. J. Roulston (1970) Resistance of ticks to chemicals. Ann. Rev. Ent. 15:381 $\sim 404$.

\section{Applied Entomology and Zoology, Vol. 8, No. 3 の目次}

藤家 样・宫下和喜 : ハスモンヨトウ雄成虫の交尾反復能力についての知見追加………........ 131

堀 浩二: マキバメクラガメの提食習性打よびその寄主植物に対する害の研究

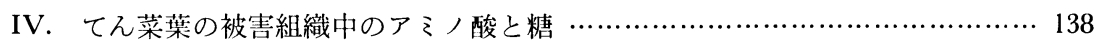

笹川満広・根岸 務：キイロコキクイムシ雌成虫つュロモンに対する行動反忘………………1. 143

伊藤嘉昭・L. O. ウォーレン：黑頭型掞よび赤頭型アメリカシロヒトリに関する研究

I. 生活史と交雑実験

服部伊楚子・伊藤嘉昭：黑頭型打よび赤頭型アメリカシロヒトリに関する研究

II. 両型掞よび交雑種の外部形態

平井一男·宮田 正・斎藤哲夫 : 有機りン剂抵抗性・感受性ミカン八ダニにおける

$32 \mathrm{P}$-ジメトエートの体内侵入 ……………….................................... 183

野出博明・寒川一成·斎藤哲夫 : ウンカ・ヨコバイ類の排泄物中のアそノ酸……………........ 191

短 報

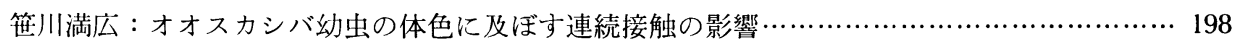

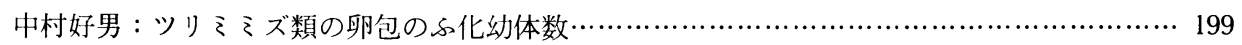

玉木佳男・野口 浩・湯嶋 健：ハスモンヨトウの性フェロモンの単兓・同定および合成……2 200 